\title{
Pithora in the Time of Kings, Elephants and Art Dealers: Art and Social Change in Western India
}

\section{Alice Tilche}

To cite this article: Alice Tilche (2015) Pithora in the Time of Kings, Elephants and Art Dealers: Art and Social Change in Western India, Visual Anthropology, 28:1, 1-20, DOI: 10.1080/08949468.2015.973255

To link to this article: https://doi.org/10.1080/08949468.2015.973255

\section{(2) Copyright Alice Tilche}

册 Published online: 03 Dec 2014.

Submit your article to this journal

III Article views: 1126

Q View related articles $\asymp$

View Crossmark data \lceil

4 Citing articles: 2 View citing articles 


\title{
Pithora in the Time of Kings, Elephants and Art Dealers: Art and Social Change in Western India
}

\author{
Alice Tilche
}

\begin{abstract}
This article analyzes the transformation of Adivasi ("Tribal") painting in western India. Drawing on theoretical approaches to the agency of art objects, it shows how from being a divinity with the power to bring prosperity, the Pithora paintings have emerged as a form of art that can be interpreted as text, and placed within new canons of beauty and style. Here this transformation is shown to be altering the semiotic processes, and the social and divine relations that the painting involves. I argue that, in becoming meaningful, Pithora is acquiring a new kind of efficacy in its ability to mediate competing processes of social and religious change.
\end{abstract}

Pithora paintings stand today for the Rathava Adivasis, just as Madhubani paintings have become iconic for the Mathila Brahmin women of northern Bihar [Brown 1996, 2006; K. Jain 2007], sand paintings for the Navajo of the western United States, and bark paintings for many Australians [Morphy 1991]. Rathavas are a group classified in the Indian constitution as "Tribal" who inhabit the hilly borderland around the town of Chhota Udaipur, the capital of an erstwhile Indian princely state nested between the regions of Gujarat and Madhya Pradesh. This article analyzes the transformation of Pithora paintings into a form of tribal art. Drawing on discussions about the agency of art objects [Gell 1998; Pinney 2004], it examines how, from being a divinity with the power to bring prosperity, Pithora is becoming a form of art that can be interpreted as text and assessed according to new canons of beauty and style. This is giving rise to new social and semiotic relations, as well as to a series of contestations over the nature of Adivasis' past and their identity. How does this transformation look from the perspective of different actors?

(C) Alice Tilche

This is an Open Access article distributed under the terms of the Creative Commons Attribution License (http://creativecommons.org/licenses/by/3.0), which permits unrestricted use, distribution, and reproduction in any medium, provided the original work is properly cited. The moral rights of the named author(s) have been asserted.

Alice Tilche holds a Ph.D. from the School of Oriental and African Studies, London, and is currently a post-doctoral fellow for the project, Rural change and anthropological knowledge in post-colonial India: a comparative "restudy" of Frederick G. Bailey, Adrian C. Mayer and David F. Pocock. E-mail: a.tilche@soas.ac.uk 
Adivasi villages in this area can stretch over kilometers, with small clusters of houses separated by hills and fields. Houses, traditionally made of mud and cow dung, are extremely spacious, with large rooms and few belongings. Pithora paintings cover the large internal walls that separate the space for the animals from the interior space of the kitchen [Figure 1 on page 9]. Painted frames mark their contours, and a central section from the periphery. The use of primary colors against a white background creates a bright contrast against the dim interior, where windows are largely absent to avoid the constant sunlight. Dominant are the color red and the figure of the horse, reproduced in the same shape across the three walls through the use of a stencil. Paintings mix mythical figures, gods and goddesses, people of authority from the present or from a royal past, and things and people of the everyday. Pithora is both the name of the painting and of the god, Baba Pithoro, who through the painting, the associated ceremony or panghu, and the mediation of the badva (healer), is called to inhabit and protect the household.

In India there have been long-standing debates about the category of "Tribe," revolving around the absolute or relative "otherness" of these populations, their "indigeneity" and their relation to caste society-the other organizing principle through which the subcontinent has been imagined [Béteille 1998; Xaxa 1999, 2005]. Although the term "Adivasi," which literally means "original inhabitants," was popularized after the 1930s as a non-derogatory term to refer to Tribals, the historical validity of such a claim remains contested [Baviskar 2005]. These debates have been not only intellectual but administrative and political, relating directly to the privileged distribution of resources and power. Adivasis' history continues to be characterized by processes of dispossession and exclusion from the forest and other resources, alongside the cultural marginalization and criminalization of these groups' livelihoods and identity [Padel and Das 2010; Skaria 1999]. Today, in eastern India, Adivasi areas are at the center of ongoing conflict between extractive industries, insurgent Maoist groups, and the Indian government [Padel and Das 2010; Shah 2010]. Around Chhota Udaipur, in Gujarat, many Adivasis are instead engaged in movements of reform and self-improvement that have long-standing roots in the area [Hardiman 1987]. These are finding a new support in the project promoted by Hindu nationalist groups, aiming to create a supposedly homogeneous Hindu nation while denying groups such as Adivasis, Muslims or Christians a distinct identity. In this process, many are seeking a separation from markers of tradition associated with their identity, including dress, food habits and ritual forms such as Pithora.

At the same time, the Indian government has been keen to promote tribal art as part of its project of diversity in unity. In this respect, Pithora is being re-evaluated as a form of art and a positive marker of indigeneity. It is today painted on canvas and circulates as a moveable, transferable and exchangeable artifact in regional and national festivals, within international art markets, museums and networks of indigenous people. Between 2008 and 2009, I conducted research in Chhota Udaipur district, focusing on the development of an Adivasi museum [Tilche 2011]. Pithora was among the rare reasons for which foreigners and middle-class Indians visited this fringe area of the region, otherwise associated from the urban point of view with poverty and criminality. While many praise the re-evaluation 
of tribal art for its empowering potential, others assess it in a more negative light as the sinister attempt to salvage what is otherwise in its essence being destroyed [Padel and Das 2010].

So far two studies have been conducted on the subject of Pithora. In a monograph written thirty years ago, the art historian Jyotindra Jain analyzes Pithora as a ritual art form, by coupling a focus on the formal aspects of the painting (material, technique, iconography and style), with a detailed analysis of the myth and the ritual connected to it. In his view, the paintings are not "ornamental wall decorations nor are they personal expressions of individual painters' worlds of thought and ideas but are a pictorial conception of the total body of myth and ritual collectively inherited from generation to generation" [1984: 2]. Jain is keen to dismantle the misconception that "all regional cultural phenomena are vernacularized offshoots of the Sanskritic great tradition" [ibid.: 1], which has resulted in the problematic reduction of so called "minor" local forms of art and knowledge. At the same time he links Pithora to the worship of Babo Ind, as the survival of the ancient Vedic and Puranic agricultural cult of Indra. In the myths that Jain collected, Babo Ind or Ind Raja (king) is the maternal uncle of Pithoro who, while having a small role in the actual painting, is central to the ceremony. It is not unusual today for people to refer to Pithora ceremonies by the name of Ind.

More recently the anthropologist Vishvajit Pandya examines Pithora as an ethnographic text through which "Rathwas visualise their world" [2004: 119]. Central to his analysis is a distinction between lakharas (writers) who literally write the painting, and the badva who reads it once complete. As for Jain, the myth of Pithoro occupies a large part of Pandya's analysis, and he uses a similar technique of "systematizing" diverse fragments and stories "to reconstruct a picture on the basis of internal evidence" [Jain 1984: 2]. Unlike Jain, however, Pandya reads this myth with a focus on the politico-economic significance of Pithora to Adivasis' life. Set against a feudal and colonial past, and a condition of contemporary scarcity, he argues that "the ritual installation of Pithoro and its reading by a Badvo are a way to reconcile Rathwa life with the continuously increasing demands of authorities who have power over them and with decreasing reproduction due to circumstances that are beyond Rathwa control" [2004: 122]. Pandya shows how the ritual of Pithora works to propitiate the space of the house and the land, and differentiate these from the "outside." As the badva reads the painting, "the painted object becomes a ritually consecrated instrument that can alter the historical experience and fortunes of the family" [ibid.: 121] and that mediates these two worlds. The representation of figures of authority such as government officials and moneylenders is simultaneously a gesture of appropriation, and by reading the painting the badva mediates their power, also associated with reading and writing [ibid.: 149].

While drawing on these studies my analysis departs from their methodological and theoretical approach, by shifting the focus from the underlying significance of the paintings to the process of signification. The article analyses the changing agency of Pithora from being a divinity, to becoming a form of art with a symbolic function, and the struggles around meaning that this involved. Benjamin has famously discussed the modern suppression of the sacred and "cultic value" of a work of art, and its substitution by its aesthetic and "exhibition value" [1968: 
224]. Following his argument, in the new secular context of modernity, art's authenticity is no longer based on its connection to ritual but to politics [ibid.]. As many authors have since argued, this distinction is much more blurred than it has been made to appear. In the Indian context Pinney [2004] and Kauri Jain [2007] have showed how mechanically reproduced images, such as the mass-produced pictures of Hindu gods often used in calendars and advertisement, may retain their divine aura and enhance belief and devotion. In this article I ask how the transformation of Pithora as art, including its divine dimension, looks from the perspective of different kinds of actor. I show how, in becoming a symbol of Rathava and Adivasi identity, the painting is becoming contested. In this process, it is gaining a new agency to mediate processes of social and religious change.

\section{PITHORA IS THE GOD}

I knew Dalasukhkaka from his occasional collaborations with the local Adivasi museum with which I was involved. After attending a Pithora ceremony (panghu) he had presided over in his own village, I asked him to tell me more about the ritual, the painting and its story. His explanations were practical, describing the ritual as a response to a problem, and detailing its unfolding.

According to Dalasukhkaka, Pithora is painted to bring well-being to a household, an explanation that echoes the studies of J. Jain [1984] and Pandya [2004]. The reasons could be many: a sick buffalo, a prolonged period of scarcity, a sick child, or an event viewed as strange. These are recurrent problems for Adivasi communities, whom Dalasukhkaka described as people "who do labor and struggle in their lives." Although there are significant differences across groups, with some such as the Bhils and the Nayaks being generally landless, and others such as the Rathavas constituting an emerging landed elite, the livelihoods of Adivasis in the area are extremely fragile. Even those who own land often have to supplement their meager income with seasonal labor migration to the cities or to other agricultural centers. The hills surrounding Chhota Udaipur, where Dalasukhkaka lives, are in fact extremely dry and barren due to deforestation [Lobo and Kumar 2009]. Soil erosion has worsened with the use of fertilizers, and with little water agriculture must rely on the unpredictability of the monsoon and one seasonal crop. Studies of labor migration conducted in the area estimate that more than half of the adult population migrates for five months each year [Mosse et al. 2002]. Dalasukhkaka himself combines diverse livelihood - as a badva (healer), a Pithora artist, and a farmer always ready to go off "doing labor" if necessity will require.

In situations of perceived misfortune, and to seek well-being, people may consult the badva, who may suggest taking a vow for Pithora. I say "may" as the badva is only one of the many solutions people recur to, including allopathic forms of medicine and gurus [Hardiman 2008]. As Dalsukhaka explained, the badva will make a first visit to the house and apply vermilion to its central wall. If things get better, the householder will then call for a panghu. Considering the large expenses that such ceremonies involve, as payments need to be made to the painters and the ritual specialists, followed by gifts and offerings of expensive food (including meat and alcohol) to both the god and large sections of the village, 
some may be unable to fulfill their duty within their own lifetime and so pass it on to the next generation instead. Besides being a solution to a problem, Pithora can also be painted as a generalized prescription of tradition, while houses in which Pithora has never been painted tend to remain "simple." The ceremony Dalasukhkaka had just presided over at Rarthyabhai's house was for a mixture of these reasons. The family's younger daughter had been sick for months, and nobody knew why. As Rarthyabhai explained, Pithora was also in their family: "it has to be done, it is because of our forefathers."

There is a season for the painting starting after the monsoons and the celebration of Dassara and ending after Holi. There are also set days of the weekfrom Monday when the wall is whitewashed, Wednesday when invitees arrive, to Thursday when the celebrations end with a feast. While the painting at Rarthyabhai's house fell on these prescribed days, there are exceptions to the routine. Painters or lakharas work in a group of six to eight males with a leader distinguished by his skill and authority. Although Pandya [2004] makes central to his analysis a distinction between lakharas who write the painting and badvas who read and interpret it once complete, there are instances in which the two roles overlap. Dalasukhkaka, for example, presided over the ceremony as the badva and leading lakhara of the group.

The painting is only one aspect of the ceremony. As painters paint, musicians play, the badva is busy with his ritual tasks, women cook large quantities of food, and friends, relatives and neighbors come and go. All this takes place in an informal atmosphere: panghus are occasions to meet and enjoy a laugh or an argument, while drinking, eating and dancing [Alles 2012: 639]. The ritual is extremely complex, and it is beyond the scope of this article to offer a detailed analysis of its unfolding. I want however to draw attention to the final ceremony, through which the badva calls Pithora to enter the painting and the household. After the gods, the ancestors, the fields and the forest had been propitiated, Dalasukhkaka entered a state of trance with the help of the dhak (a ritual drum associated with the badva). With a sword in hand and his long hair let loose, he started pointing to and naming all characters in the painting to see that nothing was missing. (A good badva is one who can spot and rectify mistakes.) Animals were then sacrificed to the painting-as-god, and the ritual ended in a feast as offerings and other foods were distributed to the invitees, according to their status and role. Pithora had now entered the house [Figure 1].

Gell [1992, 1998] offers a useful way to look at art as a form of social relation. His theory is set against anthropological approaches to art that focus on its textual and symbolic dimension - the idea that a work of art stands for something else, that art is a way through which people perceive, address or order their everyday world, and as a consequence can be read as a text [Shelton and Coote 1992]. Gell discusses art as a kind of technology [1992] that has the power to captivate the viewer by its technical virtuosity. In the context of the kula exchange famously described by Malinowski, he shows how Trobrianders' canoes, with their intricate patterns and carvings, have the effect of provoking a sense of awe in the viewer and to push them into giving more than what they might wish. Their power, he argues, lies in the interpretation of these characteristics as evidence of the magical power emanating from the thing - what he calls "the enchantment of technology." In this 
analysis the aesthetic dimension can be superseded as the focus shifts from what is beautiful or ugly to what is strong or weak, that is to say, to the question of efficacy. Munn's [1977] sophisticated analysis of the spatio-temporal conversions involved in the production-exchange cycle of Gawa canoes-from an island of Papua New Guinea that forms an important link in the kula trade ring-offers similar conclusions. Munn shows how the process of "beautification" of the canoe, which involves carving, painting and the attachment of spells and appendages, enables a series of conversions from static and inanimate material to mobile and human object. This is also a process of "enlargement" in which the canoe, by "being attractive," extends beyond the Gawan world, bringing back value [ibid.: 49]. Like Gell, she shows how a beautiful canoe "moves" kula partners to give desired valuables, while an unpainted one might negatively affect exchange [ibid.]. In Art and Agency [1998] Gell further develops this point to suggest that art objects should be understood as nexuses of social relations, and substituted as agents in the social process. This does away with a methodological distinction between people (active) and objects (passive). Instead, he suggests that the capacity to act is mediated by persons and things in a social field.

This perspective is particularly productive for understanding Pithora and the relationship between the badva and lakharas. Against the (late) Western notion of the artist as an individual genius, lakharas work under the final supervision of a god through the medium of the badva (something akin to the role of the painter in Renaissance Italian churches). At the end it is the god, through the badva, who checks the painting to see that nothing is missing. To use Gell's terminology, the god abducts the agency of the lakharas, who can from this perspective be seen more as technicians or laborers. As a god, Pithora does not mean or symbolize, but does things.

The claim that religious images are alive is not new in the Indian context. Davis shows how in Hinduism images have historically had the power to adjudicate disputes and even rule kingdoms [1999: 7]. Priests and devotees have worked to maintain their being through continuous liturgical activity, such as bathing, feeding, dressing and praising [ibid.: 6]. Pinney's seminal work on Indian photographs and chromolithographs treats images as more than a reflection of something else. Pinney juxtaposes the concept of "corpothetics" - embodied corporeal aesthetic where efficacy is the criterion of value [2004: 194] — to the classical Kantian model of aesthetic predicated on a disembodied separation between the viewer and viewed. Pinney shows how pieces of paper are turned into powerful beings through the devotee's gaze and the practice of darshan (a Sanskrit term that means "beholding" and refers to the relation between God and devotee), and through a complex repertoire of bodily performances [ibid.: 191].

After its ritual installation Pithora is treated with respect through seasonal offerings and taboos-women are for instance not allowed to touch it. There is no concern with preservation in terms of maintaining its exterior appearance, but in relation with its enduring efficacy. Pithora is left to erode and be reabsorbed into the mud walls of the house. Similarly the other gods and ancestors at the border of fields, in the form of wooden, terracotta or stone carvings, are left to re-immerse into the landscape as vegetation grows, rain falls, and materials break and mingle with the earth. Every thirty years or so, the village gods are replaced through the ceremony of Gam Shai, and Pithora may be painted again. 


\section{ADIVASIS AND SOCIAL CHANGE}

Many Adivasis in the area have become engaged historically in movements of reform and self-transformation as a response to long-term processes of economic dispossession and cultural humiliation. The reform movements that developed throughout the subcontinent during the 19th and 20th centuries, and with particular fervor in western India, promoted values of Hindu purity such as vegetarianism and abstention from alcohol. They also encouraged Adivasis to give up the widespread practice of forced labor, boycott relations with dominant castes, and form autonomous polities.

An anthropological tradition that has its roots in the early diffusionism of W. H. R. Rivers has analyzed social change through the mechanism of imitation. In India the theory of Sanskritization developed by M. N. Srinivas has looked at the push from the lower castes and tribes to imitate the traditions of their superiors [Charsley 1998]. Through a different lens, the subaltern study project has focused on the subversions implicit in the process of imitation. Hardiman analyzes reform movements as movements of assertion, to the extent that by appropriating the values of dominant groups Adivasis also implicitly redefined them [1987: 64]. Similarly, Gell talks of Adivasis' participation in the royal ritual of Dassara as a process of "coercive subordination" by which tribals, by showing deference, exalted but also neutralized the powers of the king, as the king was made powerful only by "acclamation" of the people, who therefore had a degree of control over him [1998: 436].

Today a new wave of reform is taking place through the medium of the sect. A growing number of Hindu religious sects and independent gurus are making their inroad into the area alongside development, cultural, political and religious agencies. Although stemming from different traditions, they all agree on the principle that Adivasis are essentially Hindus and should be (re)integrated into the Hindu fold. The distinction between reformed and non-reformed is today one of the strongest modes of social differentiations in the area. This division can be manifested in the adoption of a different lifestyle, and the shift away from habits and ritual forms associated with Adivasi-ness, including the consumption of alcohol (for ritual or other purposes), meat, and the belief and practice of Pithora.

Rarthyabhai was the last in his family to have an "active" Pithora in his house. Many among his relatives had moved away from this tradition and the associated practices of drinking and eating meat, by becoming reformed. After joining the Ram Dev Pir sect some had erased the god from the house by whitewashing the walls, while others had juxtaposed new figures of worship to the painting and, with the exception of elders, no longer offered the god regular sacrifices. As a consequence, some had refused to participate in the panghu that Dalasukhkaka presided over while others joined without partaking, at least publicly, of the food, drink or dancing. Although the ceremony at Rarthyabhai's place had taken place "fully," Dalasukhkaka explained how today many families asked for a "simple" Pithora, involving the substitution of animal sacrifice with the breaking of a coconut, and alcohol with Ram's juice (coconut milk). 


\section{PITHORA AS ART}

While some are erasing the god from their walls to embrace a new identity, over the last 20 years or so Pithora has also been "discovered" by urban audiences, re-evaluated as a positive form of tribal art and culture, and brought to national and international attention. Among the first agents of this transformation were Jaya Jetly (founder and president of the Dastakar Haat Samiti, ${ }^{1}$ an association that brings together craftspeople across India, since 1985), the Museum of Mankind (Bhopal), the West Zone Cultural Centre in Udaipur, and more recently the regional outlet Gurjari (Gujarat State Handloom and Handicraft Corporation). ${ }^{2}$

Some museums display Pithora within reconstructions of a tribal habitat. The Museum of Mankind called painters and members of the community to perform the ceremony. This, as a curator explained, was performed behind closed doors, due to the elements of animal sacrifice and alcohol, and their potential to upset a mixed public. Pithora however circulates more widely on canvas, without the accompanying panghu [Figure 2]. As art it is then exhibited and sold in the same museums, as well as galleries, tourist networks and regional and international festivals-cum-sales. A selected number of lakharas are as a consequence becoming artists (kalakar).

The "discovery" and popularization of rural, "folk" and "Tribal" art can be linked to the early days of exploration and colonial expansion, and to the appropriation of non-Western objects through what Clifford has termed the "art-culture system" — as objects of art or anthropology [Clifford 1998: 200]. This re-evaluation has also to do with the nostalgia generated by the industrial revolution. Over a century ago the Arts and Crafts Movement in England (1860-1910) took great interest in the promotion of traditional modes of production and ways of life [Venkatesan 2009]. Its ideas also influenced the ways in which India's villages and its crafts became envisaged as the motor behind the struggle for Independence. Finally, as being from India's internal Others, tribal art found a special place in the nation's imagination and display. Verrier Elwin, a man who greatly influenced tribal policy in the wake of Independence, argued that Adivasis constituted their own sui generis civilization. He considered Adivasis' creative impulse and aesthetic to be organically related to their social system, and called for the preservation of their arts together with their ways of life. Conversely, he argued that Adivasis' integration into a national system, their "Hinduization" and loss of habitat (land and forest), was leading to a sort of tribal depression, and to the loss of their aesthetic sense [Elwin 1951; Rousseleau 2009]. Today, although tribal art is increasingly finding a niche in the exploding Indian art market, habitat displays continue to be the most popular with respect to these communities.

Discussions of the entry of aboriginal, indigenous and other "marginal" cultural productions into the art market have shown how canons of authenticity and aesthetic beauty draw on historically sedimented judgments and categories. The nostalgia for the loss of "the Primitive" led to a rejection of hybrid objects and art forms [Philips and Steiner 1999: 9]. Moreover, as Myers suggests in the Australian context, the re-evaluation of tribal culture into art is grounded on the construction of a "permissible Aboriginal culture" [1991: 34] — a culture that is most often valued through the (colonially derived) identification of culture with race [Merlan 2001]. 


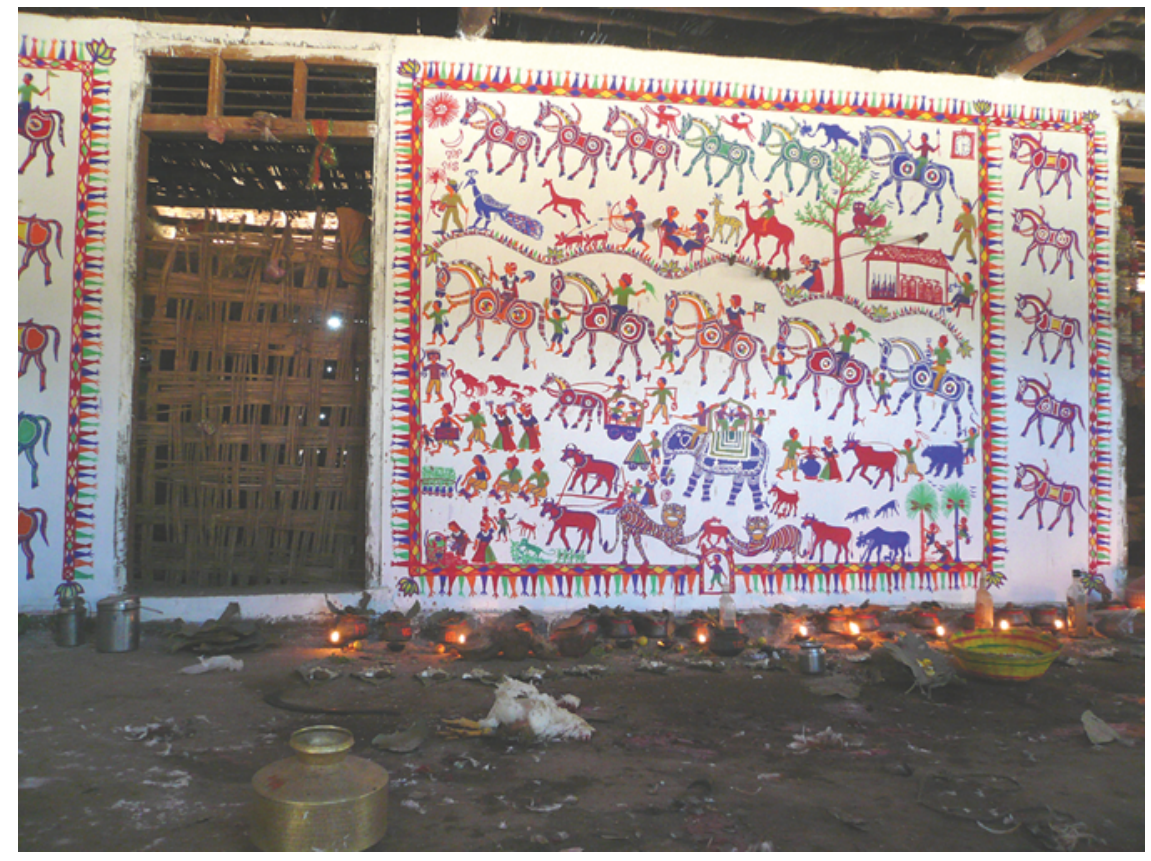

Figure 1 New Pithora after a panghu. (Photo (C) Alice Tilche)

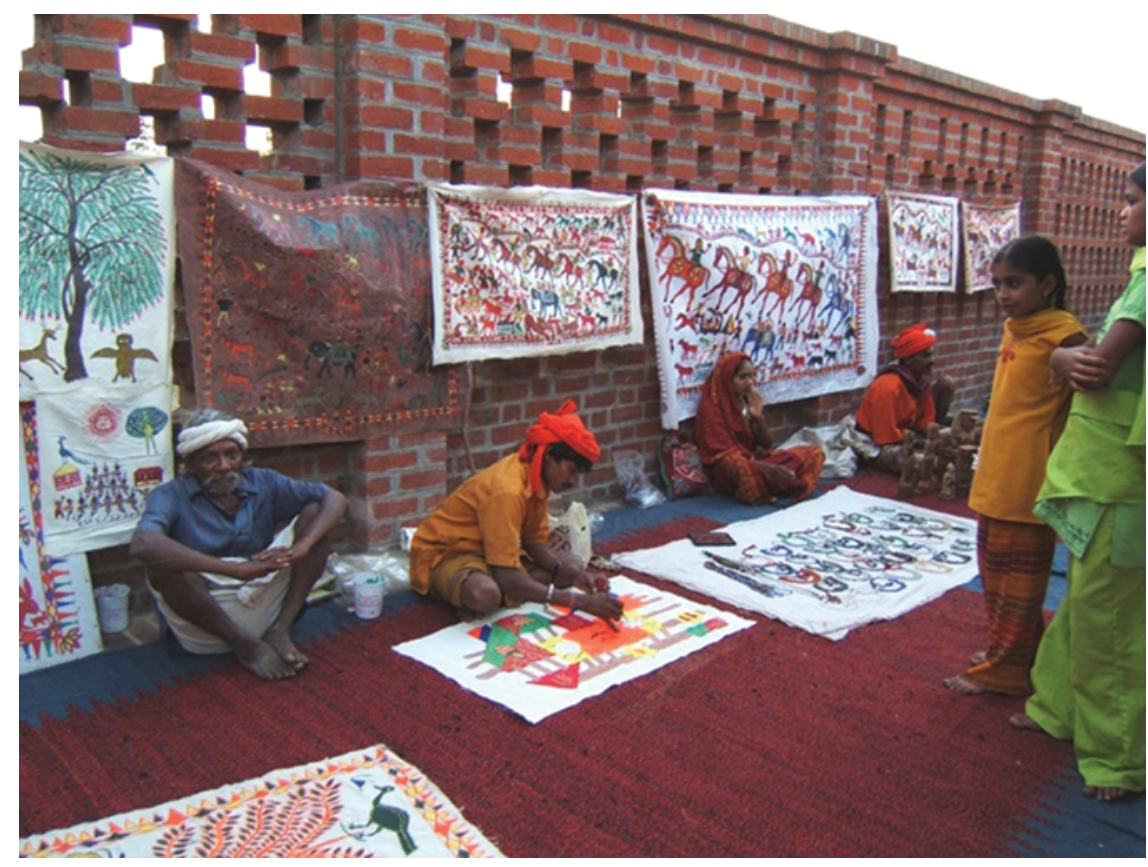

Figure 2 Sale of Pithora on canvas. (Photo (C) Alice Tilche) 
Keane's analysis [2005] of the semiotic changes in ritual speech following conversion to Christianity in the island of Sumba, Indonesia, is useful to understand the transformations of Pithora as art. His work builds on Latour's analysis of "purification" - which refers to the modern intolerance for mixing aspects of life that should be kept separate, such as the material and the spiritual, humans and non-humans, nature and society [Latour 1993]. According to Keane, with religious conversion "people's background assumption about what signs are and how they function in the world," what he labels "semiotic ideology" [2005: 194], dramatically changed. While ritual speech used to embody and bring to life the presence of ancestors, as Protestants the Sumbanese are "learning that verbal prayers are merely the expression of sincere inner thoughts that are, in essence wholly immaterial [... ]. Language, like sacrificial gods, has become "merely symbolic"' [ibid.: 199]. Ritual speech now persists as a text that carries traditional wisdom and Sumbanese ethnic identity, and the object that it denotes exists independently from the performance of speaking this text. In this new representational economy the concern is no longer with achieving effective communication with ancestors but with matters of interpretation. The direction of ritual speech has also changed, from addressing ancestral figures, to an audience.

In his history of India through images Pinney examines the colonial effort at transposing images from the space of devotion to the one of representation - a process that can also be discussed as an instance of "purification." This involved a conflict between a Kantian understanding of aesthetic based on the distancing from the body, and between observer and observed, and an indigenous concept that instead emphasized a fusion of the two [Pinney 2004: 19]. However, it would be mistaken to assume the success of this new semiotic ideology. For Keane attempts at purification are constantly prone to slippage. Pinney shows how colonial efforts at undermining the cultic value of images only worked to strengthen it. Colonial realism was reappropriated as "magical realism." Instead of becoming mere icons the gods became more real [ibid.: 31; K. Jain 2007], and their increased circulation and consumption made them more powerful.

In the next sections I show how, with the shift to art Pithora is turning into a text that speaks of Adivasis' history and identity. In this guise its validity is no longer assessed by the god via the badva but by a wider audience in terms of canons of beauty and authenticity, and of a "true story" behind the painting. How are Pithora's power and divine dimension being refigured and negotiated?

\section{A FINISHED AND TRIBAL STYLE}

In order to circulate successfully as Art, Pithora paintings should be visibly tribal. An art connoisseur visiting the area explained how consumers appreciate the boldness of the paintings' traits, their vibrant colors and their simplicity. Being visibly tribal also means being associated with the tribal body. During art festivals and museum exhibitions, artists are generally encouraged not only to be but to look tribal.

At the same time, the "tribal" is a category that should be improved and a series of craft schemes, run by government agencies and NGOs, work to train Pithora 
artists [Venkatesan 2009]. Artists are generally taught to produce smaller decorative pieces, with motifs that, while maintaining a tribal essence, should not differ too much from the "mainstream." On canvas, they paint a modified version of Pithora that only features the central section of the painting. They also produce smaller pieces which feature enlarged characters from the painting as well as representations of Hindu gods and goddesses [Hacker 2000].

The circulation of Pithora outside is introducing new terms of evaluation back in the village. Kanchankaka is today one of the most famous artists in the area. He is the first, and to the best of my knowledge the last, who has traveled to London with his art. For this, despite his lack of education, "poor" background and traditional attire, he is well respected by elite sections of the community as well as by non-Adivasis. In his view, before Pithora "was not so good," as people did not "finish" the painting. According to Kanchankaka, "finishing" means paying greater attention to detail such as drawing borders around all characters. This also relates to changes in the economy and material used. Traditionally the primary colors employed in the painting were procured from natural materials such as kaju flowers for vermilion and turmeric for yellow. Today they are prepared by mixing powder colors with milk. Before, paintings were written directly on mud walls, while today, lakharas whitewash the walls beforehand. This avoids the fast absorption of colors, giving the painting more durability and a shiner look, and making new Pithoras distinctive from old ones, that instead resemble the ancient rock paintings widely found in the area [Figures 1, 3 and 4]. Alongside style, new modes of representation are also taking shape. Kanchankaka and his team now ask villagers if they want sex scenes to be depicted on their wall. In more recent paintings, they inserted new icons derived from the Hindu pantheon, such as the character of the elephant god Ganesh.

The boundaries of modification, and of what counts as a successful artist and representation, are hard to gauge. Dalasukhkaka, the badva and lakhara I introduced in the previous section, never became as famous. The reasons for an artist's success have as much to do with relations of patronage as with individual genius [Tilche 2011: 196-226]. According to the perspective of more successful artists, Dalasukhkaka's paintings were not so good because his style was too "rough." At the same time, while "the tribal" should improve it should not become like the mainstream. When a young emerging artist from the area tried to sell the representation of an urban landscape, he was discouraged by his patrons, as "there is plenty of that other stuff in the cities." In the context of tourist art Steiner usefully discusses how the search for the authentic may lead to such paradoxical requirements. While anything that deviates from a particular "ethnic style" is judged inauthentic, objects that remain too traditional are deemed inauthentic by serious collectors, as they are not produced in the ritual context of customary use [1999: 101].

\section{AN EMERGING STORY}

The art historian Jyotindra Jain [1984] and the anthropologist Pandya [2004] center their analysis on the myth behind Pithora. In contrast, I have stressed the 


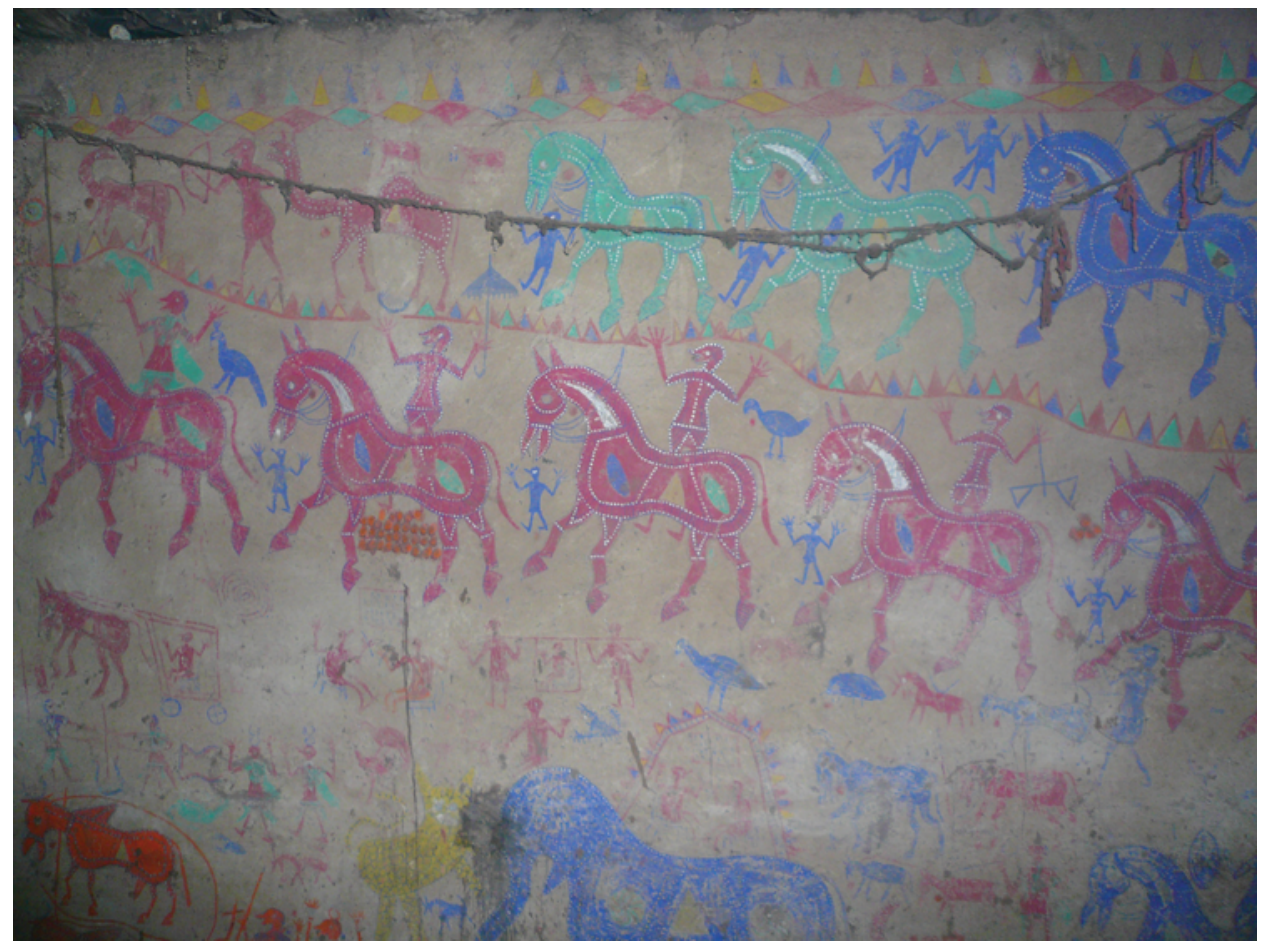

Figure 3 An aged Pithora on a house wall. (Photo (C) Alice Tilche)

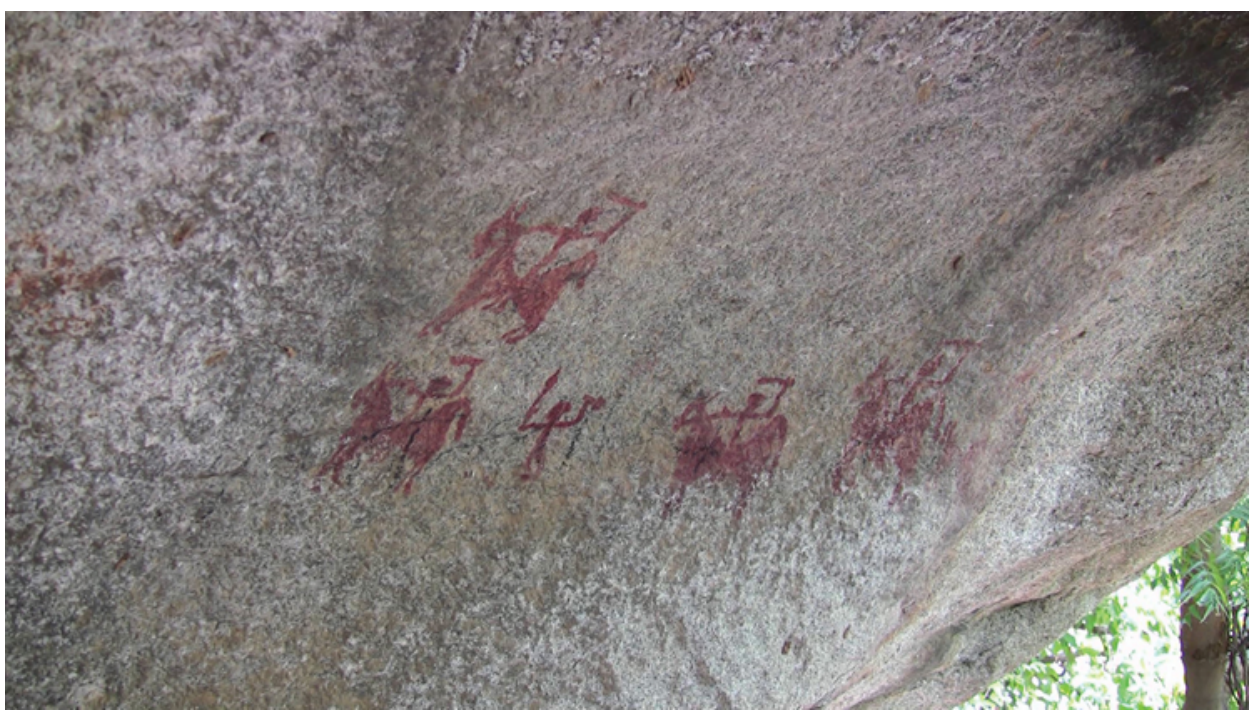

Figure 4 Rock paintings with horse figures. (Photo (C) Alice Tilche) 
effectiveness of the painting over its meaning. Dalasukhkaka laughed at the people, including myself, who came to the area looking for Pithora paintings and asking for their story. In villages there was no story. Most lay people pointed to the badva for information. Badvas avoided Pithora questions and when cornered remained frustratingly vague in their explanations - their knowledge was not there for everybody to understand. Nobody could fully translate Dalsukhkaka's mumbled speech during the last ritual of the panghu. But nobody listened with the aim of decoding his words. Even lakharas did not really know, and pointed to the badva for information.

As I spent time with badvas, some eventually agreed to tell. Their goodwill was however not always helpful. Badvas recited the story as if possessed, in a cantilena of high pitches and soft murmurs which made it difficult to distinguish one word from the next. These accounts varied according to badva and to village, and became intelligible only after days of painstaking translation. During this process, a story gained coherence, but it also turned into something quite different from their original mumbled speech.

The transformation of Pithora into Culture and Art is bringing a new concern with meaning and interpretation. Anthropologists, tourists and art dealers are not the only ones interested in the story. Badvas, lakharas and other lay people in villages are also learning to produce their own competing versions. Initially Pithora stories sounded contradictory, illogical and even hallucinatory to outsiders. Now they are becoming increasingly standardized and translatable to an audience. The story that circulates as part of the National Consortium of Tribal Arts and Culture (NCTAC) ${ }^{3}$ goes as follows: after being raped, Kali Koyal gave birth to an illegitimate child, Pithoro, and left him in the jungle. Rani Khajal stumbled upon the crying child while grazing her animals and rescued him, becoming his foster mother. Pithoro grew to become a king, and married Pithori. The story of Pithoro growing up to become king, despite all odds, represents the possibility of success, while bringing auspiciousness to the house.

\section{FROM LAKHARA TO KALAKAR}

How do people relate to the commercialization of the painting, especially considering its sacred nature? There had been debates in the community around this question. While Pithoras were initially painted with the accompanying panghu, people had later agreed that it would be best to reproduce them without the ceremony. According to Kanchankaka, the famous Pithora artist from the area, in this way Pithora would be of no comparable value to the originals. Kanchankaka had no objection to the circulation of Pithora: "Why should people get upset over a painting without the ceremony? It is like the figure of [the god] Ram on television or on posters. Are people upset about Ram?"' For Kanchankaka, Pithora has become an icon with the positive potential to bring visibility and economic benefits to the community. "Our Adivasis should be proud that others know." His is however the perspective of a successful artist. According to Dalasukhkaka, who is well known in the area for his healing powers but less famous outside, the circulation of Pithora was a big mistake. After the panghu I described earlier, 
Dalasukhkaka had agreed to tell me the "story" of Pithora. At the end of his narration, he added:

Dalasukhkaka: I tell you what, sister, we have sold our Pithora. Our Pithora is now all over the world, in every country and every place; it is our fault, not yours. In telling our story, we have done some wrong. The reason being that this is our religion, it is our lineage god, our sacred place, and we have given it to you. And then, nobody comes here and asks [...], and nobody knows about the ritual. This is our mistake. I spoke with you today, otherwise I have never told the story to anybody.

Alice: Why do you call it a mistake?

Dalasukhkaka: What comes back to us? After you have recorded it [he is now pointing at my recorder and speaking softly, as if not to get heard], you will go back to your country [...] you have filmed how we make panghu [imitates me filming with the camera and laughs], you know how colors are mixed, how the drawing is done, you know everything, there is nothing that you do not know: then what? ${ }^{4}$

Dalasukhkaka's comments need to be understood in relation to the changing relations of patronage and the traditional division of labor that linked badvas, lakharas and god. Some lakharas are now emerging as individual artists, out of what was a collective creation [Barucha 2003]. As such, they are no longer subordinated to the god through the badva but to demands of the art market and other patrons. Famous lakharas like Kanchankaka now take the liberty of altering characters in the painting with no consultation, and have become storytellers, popularizing the protected knowledge of Pithora. This is feeding into a process of marginalization of the badva in the face of modernity, in relation to the increasing importance of new religious sects and allopathic forms of medicine. In this process Pithora ceremonies and the $b a d v a$ 's role as ritual specialist are being hollowed out. It is in this light that Dalasukhkaka described Pithora on canvas as empty and powerless, and commented with a negative tone that "they have all become artists."

Dalasukhkaka however was not against the circulation of Pithora per se. He himself occasionally painted Pithoras on canvas and sold them to the few tourists to visit his house. Lately however his business had not been going so well, as artists such as Kanchankaka and his family had taken over patronage networks from and to the area. To his challenging question, "what comes back to us?" there was not much I could in fact say, other than acknowledging and reflecting on the unequal relations that underpin our encounter. In this sense the re-evaluation of traditions into art - what Clifford [1997] has analyzed as a powerful tool for redressing marginality - is also giving rise to new kinds of inequality.

\section{CONTESTED MEANING: ART AND SOCIAL CHANGE}

In the process of meaning-making, as Pithora's signifier and signified become detatched, conflict is emerging in determining their relation. The painting is becoming implicated in competing claims about Adivasis' past and their identity. Adivasi and non-Adivasi activists and social workers linked to cultural organizations, NGOs and social movements concerned with the preservation of Adivasi traditions, stress the indigenous origins of Pithora. Following a debated trend 
in ethno-archaeology that is now connecting ancient rock art to contemporary Adivasis' expressive traditions [Chakravarty and Badam 1998], their historical reconstructions link Pithora to the rock paintings widely found in the area [Figure 4]. Although dating continues to be an issue of contention within archaeological debates, rock art is here taken as proof that Adivasis inhabited the area since millennia ago. Figures of the horse, depicted in both Pithoras and rock paintings, underscore these similarities. Others link Pithora to the time of the kings, and a more recent past of princely rule. According to both Kanchankaka's and Dalasukhkaka's reconstruction, before Pithora was only painted in the royal palace during the annual festival of Dassara. It was by imitating the king that lay people started painting it in their homes. J. Jain also stresses the Rajput influence in the painting's iconography. According to his analysis paintings in neighboring regions that were not affected by princely rule resemble "archaic cave paintings." In contrast, Pithora portrays an elaborate marriage procession with regal-looking dresses, ornaments and caparisons [1984: 16] — what his informants also described as a faithful representation of the Dassara procession in the former state of Chhota Udaipur.

The painting is becoming a debated marker of the increasing process of Hinduization affecting the area. Dhaniben, a member of an Adivasi cultural organization active in the protection of gender rights, was concerned with how new Pithoras depict women with a veil covering their head, unlike older ones where their heads are uncovered. Dhaniben related this shift to the influence of more conservative Hindu modes of comportment. Another point of contention is the identification of figures within the painting with gods from the Hindu pantheon. Recently, Kanchankaka and his team had started painting the elephant god Ganesh sitting cross-legged outside the central frame of the painting [Figure 5]. In telling Pithora's story, they referred to some figures by the names of Hindu gods. These included the first horse painted in the frame, alternatively called Haneh and Ganesh, and Barmata (twelve heads) a character whose head is made of twelve candles also identified as Ravan, the demon from the Ramanyana that has multiple heads. Historical reconstructions promoted by the Sangh Parivar ${ }^{5}$ and the various religious sects and political agencies at work in the area portrayed these overlaps as evidence of the essentially Hindu character of Adivasi society. For Dhaniben, on the contrary, the horse Haneh had nothing to do with the elephant god Ganesh, which was a very recent, and in her view misplaced, insertion. The representations that circulate nationally as part of the National Consortium of Tribal Arts and Culture also explicitly mark these differences [J. Jain 1984: 29].

Rather than simply pointing to the modern politics of Hinduness (Hindutva), these overlaps can be related to a long history of interconnectedness between groups, and the relatively recent emergence of "Hindu" and "Adivasi" as political identities [Guha 1999]. While Adivasis are not always Hindus their traditions developed in relation to Hindu and other cultural traditions such as Islam. Since the 19th century Adivasis' reform movements grew in relation to an internal quest for betterment, and to the influence of external agencies. The festival of Ganapati (Ganesh), for instance, is a new insertion in the local landscape that is being promoted and subsidized by groups linked to the VHP (United Hindu Family). It is an addition that is not going unnoticed, as the festival involves the installation at 


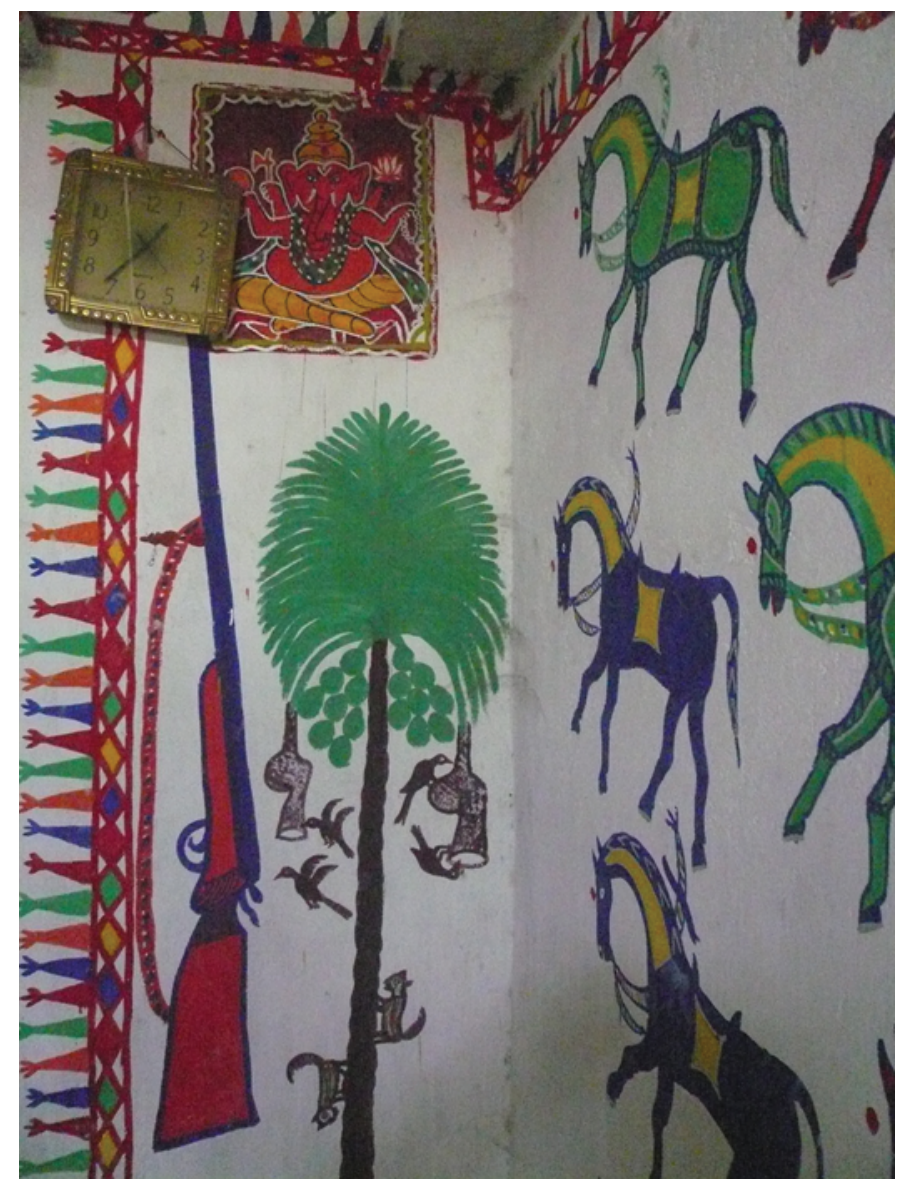

Figure 5 Ganesh figure on the top corner of the wall. (Photo (C) Alice Tilche)

the center of the village of a giant icon of the elephant god with an incorporated sound system. Ganesh is also painted for auspiciousness during new marriage practices directed by the Brahmin rather than the badva, on the same internal wall of the house where Pithora would have been. Like Pithora, the elephant god looks after the household and ensures its well-being. This might help to explain how Haneh, the first horse painted in the frame, could become Ganesh, a god Hindus regularly invoke at the start of ceremonies for the removal of obstacles.

When I asked Kanchankaka why he started painting Ganesh in his Pithora, his answer was: "It looks beautiful, and people like it." In this respect, the transformation of Pithora relates to the requests of the local art market and the taste of its diverse consumers. It may also have to do with the new taste and aesthetic that are developing within Adivasi communities, alongside new modes of devotion. Kanchankaka was not a devout Hindu, and continued to worship Pithora in his house. Against the walls where Pithora was painted, however, he had also hung posters of Hindu gods, a move for which he had another simple explanation: "It is good." 
For Gell the "art nexus" is made of an ambiguous and shifting net of social relations. As I showed, art objects are themselves an outcome and an instrument of social agency. But agency is not static and essential to one person, object or situation. It can be "abducted" and depends on the positioning of index (the art object), artists, prototypes (a historical individual or a deity) and recipients vis-àvis one another [Gell 1998: 28-59]. An index may have power over its audience or recipient, and it is in fact an agent only to the extent that there is a recipient. As I showed while discussing style, the kinds of material used in the old and the new paintings also encourage different interpretations and duration in time. The finished look of new Pithoras, made possible by the use of new kinds of color and brush, is making Pithora available in a "modern" form both to the "outside" and to a local audience that is otherwise detaching itself from the belief in the god. The artist, from being the witness of an act of creation (acting on behalf of the god) may become the source of a creative act, as an agent and author. There might however be secondary agents, such as new patrons, art dealers and other gods, to influence the form and style of the painting. At the same time, the material aspect of these interpretations makes them continuously open for contestation and change. As things age, circulate and are reshaped by time and people, they cannot be reduced to a single story but invite new responses that might be different from the original intentions of makers: a horse may therefore transform into an elephant, then into something else.

\section{CONCLUSION}

Following Gell and Munn, I have considered art as a form of social relation and aesthetics as an object's ability to do things, and to move people to do things [Munn 1977: 51]. In the ritual context of villages, I have shown how Pithora can be understood as a form of art for its ability to affect the fortunes of a family by bringing cure, protection and prosperity, and for mediating between the world of the mundane and the divine. As the material and the spiritual dimension are fused into one, the aesthetic appreciation of the painting relates more to a concern with maintaining its efficacy than with its visual qualities.

In becoming a recognized form of art Pithora is undergoing a series of transformations that are altering its materiality, and the semiotic and social relationships that it involves. Pithora features new motifs against the erasure of others. It is also taking on a "finished" style, as compared to the rougher paintings of the past. Although the painting is circulating widely, elements of sacrifice and alcohol traditionally associated with the ceremony do not circulate so easily. Importantly Pithora is acquiring new meaning in becoming a text which can be read-not only by the ritual specialist, as a form of communication between spiritual and human realms, but by museum curators and art critics, as a form of communication between a culture and its audience. This is promoting a new division of labor that is privileging emerging individual artists against the traditional ritual role of the badva.

These changes are taking place in relation to representations of others, and to the new canons of aesthetic beauty and authenticity introduced by museums and the art market. They also relate to processes of social transformation under 
way in Adivasi society. As reformed Adivasis are distancing themselves from traditions such as animal sacrifice that they now consider "backward," these same practices are also discouraged in museums, or the houses of middle-class consumers, where alterity proves most translatable and successful when normalized. Moreover, as I have shown, change not only depends on the power of ideologies but also rests on the materiality of the paintings.

In becoming text the painting is perhaps dissociated from the power of the god Pithora. As Art, however, it is also gaining a new agency through its renewed ability to bring prosperity and recognition, and to mediate between different projects of social and religious change. The transformations (new style, characters and meaning) that accompany the re-evaluation of Pithora are making it available in a more "modern" form not only to the "outside" but also to those reformed sections of the community that are distancing themselves from such traditions. They are also in some way renewing its divine agency and spiritual dimension, in relation to new practices of devotion within Adivasi communities. At the same time these changes have the potential to overlap with other interventions and interpretations, such as the political project of integrating Adivasis within the Hindu fold. As during the time of the kings, when Pithora mediated between kingly, divine and mundane political economies by appropriating elements of royal processions, today it is mediating the push and pull of Adivasis between Hindu and indigenous traditions with the demands of the market and its diverse consumers.

\section{NOTES}

1. See http://www.indiancraftsjourney.in/whoweare.htm (accessed April 20, 2013).

2. See http://www.gurjari.co.in/ (accessed April 20, 2013).

3. NCTAC is a digital repository for tribal art funded by the Ministry of Culture. See http:/ /www.tribalartsmuseums.org/nctac.html (accessed March 21, 2012).

4. Interview with Dalasukhkaka, April 7, 2009.

5. The Sangh Parivar is an umbrella of Hindu organizations that includes the RSS (Rashtriya Swayamsevak Sangh-National Volunteer Union), the BJP (Bharatiya Janata Party-Indian People's Party) and the VHP (Vishva Hindu Parishad-World Hindu Council), among others. For an extensive discussion of the rise of Hindu nationalism in Indian politics and culture, see Hansen [1999].

\section{REFERENCES}

\footnotetext{
Alles, Gregory D.

2012 Tribal Chic: Crossing Borders in Eastern Gujarat. Journal of the American Academy of Religion, 80(3): 623-658.

Barucha, Rustom

2003 Rajasthan: An Oral History. Delhi: Penguin.

Baviskar, Amita

2005 Adivasi Encounter with Hindu nationalism in Madhya Pradesh. Economic and Political Weekly, 40: 5105-5133.

Benjamin, Walter

1968 The Work of Art in the Age of Mechanical Reproduction. In his Illuminations. Hannah Arendt, ed.; Harry Zon, trans. Pp. 217-253. New York: Schocken.
} 
Béteille, André

1998 The Idea of Indigenous People. Current Anthropology, 39(2): 187-191.

Brown, Carolyn H.

1996 Contested Meanings: Tantra and the Poetics of Mithila art. American Ethnologist, 23(4): 717-737.

2006 Documenting the Image in Mithila Art. Visual Anthropology Review, 22(2): 5-33.

Chakravarty, K. K., and G. L. Badam

1998 Rock Art and Archaeology of India. New Delhi: Agam Kala Prakasham.

Charsley, Simon

1998 Sanskritization: The Career of an Anthropological Theory. Contributions to Indian Sociology, 32(2): 527-546.

Clifford, James

1997 Routes: Travel and Translation in the Late Twentieth Century. London: Harvard University Press.

1998 The Predicament of Culture: Twentieth-century Ethnography, Literature, and Art. Cambridge, MA: Harvard University Press.

Davis, Richard H.

1999 Lives of Indian Images. Delhi: Motilal Banarsidass Publishers.

Elwin, Verrier

1951 The Tribal Art of Middle India: a Personal Record. Bombay: Oxford University Press.

Gell, Alfred

1992 The Technology of Enchantment and the Enchantment of Technology. In Anthropology, Art and Aesthetics. Jeremy Coote and Anthony Shelton, eds. Pp. 40-66. Oxford: Clarendon Press. 1998 Art and Agency. Oxford: Oxford University Press.

Guha, Sumit

1999 Environment and Ethnicity in India 1200-1991. Cambridge: Cambridge University Press.

Hacker, Katherine F.

2000 Traveling Objects. Brass Images, Artisans and Audiences. Anthropology and Aesthetics, 37(Spring): 147-165.

Hansen, Thomas B.

1999 The Saffron Wave: Democracy and Hindu Nationalism in Modern India. Princeton: Princeton University Press.

Hardiman, David

1987 The Coming of the Devi: Adivasi Assertion in Western India. Oxford: Oxford University Press.

2008 Missionaries and Their Medicine: A Christian Modernity for Tribal India. Manchester: Manchester University Press.

Jain, Jyotindra

1984 Painted Myths of Creation: Art and Ritual of an Indian Tribe. New Delhi: Lalit Kala Academy. Jain, Kauri

2007 Gods in the Bazaar: the Economies of Indian Calendar Art. Durham, NC: Duke University Press. Keane, Webb

2005 Signs Are not the Garb of Meaning: On the Social Analysis of Material Things. In Materiality.

Latour, Bruno Daniel Miller, ed. Pp. 182-205. Durham, NC: Duke University Press.

1993 We Have Never Been Modern. Catherine Porter, trans. Cambridge, MA: Harvard University Press.

Lobo, Lancy, and Shashikant Kumar

2009 Land Acquisition, Displacement and Resettlement in Gujarat: 1947-2004. New Delhi: Sage Publications.

Merlan, Francesca

2001 Aboriginal Cultural Production into Art: the Complexity of Redress. In Beyond Aesthetics: Art and the Technology of Enchantment. Christopher Pinney and Nicholas Thomas, eds. Pp. 201-234. Oxford: Berg.

Morphy, Howard

1991 Ancestral Connections. London: University of Chicago Press. 
Mosse, David et al.

2002 Brokered Livelihoods: Debt, Labour Migration and Development in Tribal Western India. Journal of Development Studies, 38(5): 59-88.

Munn, Nancy D.

1977 The Spatiotemporal Transformation of Gawa Canoes. Journal de la Société des océanistes, 33(54-55): 39-53.

Myers, Fred

1991 Representing Culture: the Production of Discourse(s) for Aboriginal Acrylic Paintings. Cultural Anthropology, 6(1): 26-62.

Padel, Felix, and Samarendra Das

2010 Out of this Earth: East India Adivasis and the Aluminium Cartel. New Delhi: Orient BlackSwan.

Pandya, Vishvajit

2004 Rathwa Pithoro: Writing about Writing and Reading Painted Ethnography. Visual Anthropology, 17(2): 117-161.

Philips, Ruth B., Christopher B. Steiner

1999 Introductory Remarks. In Unpacking Culture: Art and Commodity in Colonial and Postcolonial Worlds. Ruth B. Philips and Christopher B. Steiner, eds. Pp. 3-20. Berkeley: University of California Press.

Pinney, Christopher

2004 Photos of the Gods. The Printed Image and Political Struggle in India. London: Reaktion Books.

Rousseleau, Raphael

2009 L'invention de 'l'art tribal' de l'Inde : Verrier Elwin 1951. In Histoire de l'art et d'anthropologie. Shah, Alpa Pp. 53-62. Paris: Colloque du Musée du quai Branly; INHA.

2010 In the Shadows of the State: Indigenous Politics, Environmentalism and Insurgency in Jharkhand, India. Durham, NC: Duke University Press.

Shelton, Anthony, and Jeremy Coote

1992 Introduction. In Anthropology, Art and Aesthetics. Jeremy Coote and Anthony Shelton, eds. Pp. 1-15. Oxford: Clarendon Press.

Skaria, Ajay

1999 Hybrid Histories: Forests, Frontiers and Wildness in Western India. Delhi: Oxford University Press.

Steiner, Christopher B.

1999 Authenticity, Repetition and the Aesthetics of Seriality: the Work of Tourist Art in the Age of Mechanical Reproduction. In Unpacking Culture: Art and Commodity in Colonial and Postcolonial Worlds. Ruth B. Philips and Christopher B. Steiner, eds. Pp. 87-104. Berkeley: University of California Press.

Tilche, Alice

2011 In Search of an Adivasi Worldview: Identity, Development and the Adivasi Museum of Voice in Western India. London: SOAS, University of London; Ph.D. dissertation in Anthropology.

Venkatesan, Soumhya

2009 Craft Matters: Indian Artisans, Development and the Indian Nation. New Delhi: Orient Longman. Xaxa, Virginius

1999 Tribes as Indigenous People of India. Economic and Political Weekly, 34(51): 3589-3596.

2005 Politics of Language, Religion and Identity: Tribes in India. Economic and Political Weekly, 40(13): 1363-1370. 